УДК 378[016:81'243]:004

(C) Черненко А.В., 2019 p.

https://orcid.org/0000-0003-4097-6246

DOI: $10.34142 / 23128046.2019 .46 .13$

А. В. Черненко

\title{
ВИКОРИСТАННЯ СОЦІАЛЬНИХ МЕРЕЖ ДЛЯ НАВЧАННЯ СТУДЕНТІВ У ЗАКЛАДАХ ВИЩОЇ ОСВІТИ
}

Сьогодні, зі стрімким розвитком мережі Інтернет, вже не можливо уявити сучасну людину, яка б не користувалась он-лайн комунікачіями. Одним із пріоритетних напрямів розвитку освіти України є впровадження сучасних технологій, які забезпечують удосконалення навчально-виховного процесу, доступність та ефективність освіти, підготовку молодого покоління до життєдіяльності в інформаційному суспільстві, щзо визначає актуальність дослідження. Інформаційно-комунікаційні технології в освіті допомагають викладачам реалізувати ефективне викладання матеріалу, використовуючи новітні засоби, які сприяють досягненню позитивних результатів. Технології змінюються, що в свою чергу потребує від студентів та викладачів вдосконалення свойх вмінь і постійного розвитку. 3 розвитком соиіальних мереж також виникає нагальна потреба використовувати їх у прочесі навчання. Стаття присвячена проблемі застосування соціальних мереж у навчальному прочесі закладів вищої освіти. Метою статті $\epsilon$ дослідження та виявлення можливостей використання навчальних додатків сочіальних мереж та пошук зручних засобів для навчання студентів у закладах вищої освіти. Для досягнення мети використано загальнонаукові методи теоретичного рівня: аналіз, синтез і систематизація праць авторів із проблеми дослідження соціальних мереж; логіко-системний, проблемно-иільовий, порівняльний аналіз з метою теоретичного обтрунтування особливостей навчальних додатків соиіальних мереж. Результати дослідження полягають у низиі напрацювань. У роботі зроблений аналіз історії виникнення соиіальних мереж та розглянуті етапи їх розвитку. Представлена світова статистика використання соиіальних мереж. Описані основні характеристики та потенційні можливості найбільшої соиіальної мережі Facebook. Завдяки зазначеній мережі та навчальним додаткам шлях до навчального матеріалу стає більш доступним, а сама надана інформація стає більш цікавою та різноманітною. Особлива увага у роботі приділена організації навчання студентів у сочіальних мережах, що осучаснює комунікацію між викладачем i студентом. Розглянуті та описані найбільш затребувані соиіальні мережі та додатки для навчання. Визначені переваги та недоліки використання соиіальних мереж в освітньому процесі. Виділені основні характеристики функціонування віртуальних соџіальних мереж для навчання студентів. 
Ключові слова: студент, навчання, соціальні мережі, навчальні додатки, інформаційно-комунікаційні технології, Інтернет комунікаиії, Facebook.

Chernenko A. V. The use of social networks in higher education institutions. Nowadays, as for Internet development, it is not possible to imagine a modern person who does not use online communications. One of the priority directions of the education development in Ukraine is the use of up-to-date technologies, which provide education improvement, accessibility and efficiency, training young generation for life in the digital society. It reflects the research topicality. Information and communication technologies in education help teachers to teach the content effectively using the latest means that contribute to the achievement of positive results. Technologies are changed, in turn it requires from students and teachers to improve their skills and to focus on the development. With the development of social networks, there is an urgent need to use them in learning. The article is devoted to the problem of using social networks in universities in learning students. The purpose of the article is to explore and identify opportunities for using social networks and to find convenient tools for students' learning in universities. To achieve the purpose the general theoretical scientific methods are used such as analysis, synthesis and systematization of researchers' works as for social networks; logical-systemic, problem-targeted, comparative analyses as for theoretical basics of social networks. There are some research results. The analysis of coming out history of social networks is made, and the stages of their development are considered. The world statistics of social networks usage are considered. The main characteristics and potential features of the largest social network Facebook are described. Due to Facebook and apps, the access to learning content is getting better, and the information becomes much more interesting. The particular attention is paid to organizing students' learning in social networks that provides better communication between a teacher and a student. The most popular social networks and apps for learning are described. The advantages and disadvantages of using social networks in education are determined. The basic characteristics of virtual social networks functioning are highlighted.

Keywords: student, learning, social networks, apps, information and communication technologies, Internet communications, Facebook.

Вступ. У Національній стратегії розвитку освіти в Україні на період до 2021 року (Pro Natsionalnu stratehiiu rozvytku osvity v Ukraini na period do 2021 roku, 2013) викладені основні тенденції розвитку освіти в найближчий час, що обумовлює актуальність даного дослідження. Одним із пріоритетних напрямів розвитку освіти $є$ впровадження сучасних технологій, що 
«забезпечують удосконалення навчально-виховного процесу, доступність та ефективність освіти, підготовку молодого покоління до життєдіяльності в інформаційному суспільстві» (Pro Natsionalnu stratehiiu rozvytku osvity v Ukraini na period do 2021 roku, 2013). В умовах суцільного використання новітніх технологій, розпочинаючи вже з дитинства, формується суспільство, яке, на наш погляд, спирається на масове залучення до новітніх технологій (Chernenko, 2018).

Ми впевнені, що все більша глобалізація процесів навчання в Україні потребує інформаційно-комунікаційного простору, що, в свою чергу, сприяє обміну великої кількості інформації (Chernenko, 2019). Сьогодні, зі стрімким розвитком мережі Інтернет, вже не можливо уявити сучасну людину, яка б не користувалась зазначеною мережею. Технології змінюються, це потребує від викладачів і студентів постійного розвитку.

Особливу увагу у навчанні привертають соціальні мережі. Зручність соціальних мереж полягає в тому, що вони загальнодоступні, більшість функцій $є$ безкоштовними. Використання соціальних мереж $\epsilon$ досить ефективним засобом для навчання студентів, а також засобом удосконалення знань і умінь студентів. Студенти - це активні користувачі соціальних мереж, які більшу частину свого вільного часу проводять в Інтернет-просторі.

Припускаємо, що викладач є сучасним, коли він говорить «мовою» студента. Вважаємо, що сучасність викладача можна визначити наступним чином - це вільне володіння інформаційно-комунікаційними технологіями, якими користуються студенти. Саме тому, щоб бути викладачем нового покоління необхідно постійно залучати до процесу навчання новітні технології.

Отже, соціальні мережі відіграють навчальну та пізнавальну роль. Це надає викладачам можливість реалізувати ефективне викладання матеріалу, використовуючи всі новітні технології, які сприяють досягненню позитивних результатів у навчанні. 
Не зважаючи на доволі новітній характер, дослідженню сутності поняття «соціальна мережа» на сучасному етапі присвячено кілька праць вітчизняних учених, зокрема, праці К. Балабанової (Balabanova \& Vakariev, 2013), Д. Бодненко (Bodnenko, Yashchenko \& Borshch, 2012), О. Власенко (Vlasenko, n. d.), С. Івашньової (Ivashnova, 2012), І. Костікової (Kostikova, Shevchenko, Holubnycha, Popova \& Budianska, 2019), (Kostikova, Viediernikova, Holubnycha \& Miasoiedova, 2019), (Kostikova, 2018), А. Яцишин (Yatsyshyn, 2014) та ін.

У своїх дослідженнях вчені аналізують використання соціальних мереж, як для потреб загальної середньої освіти, так і вищої. На відміну від зазначених досліджень, основну увагу ми приділяємо використанню навчальних додатків соціальних мереж для навчання студентів у закладах вищої освіти.

Мета та завдання. Метою статті $є$ дослідження та виявлення можливостей використання навчальних додатків соціальних мереж та пошук зручних засобів для навчання студентів у закладах вищої освіти. Завдання статті полягає в аналізі соціальних мереж та навчальних додатків; визначенні їх переваг, недоліків та перспектив використання у навчанні; виокремленні можливостей, які вони надають у покращенні навчання студентів.

Методи дослідження. Для досягнення мети, розв'язання окреслених завдань дослідження було використано загальнонаукові методи теоретичного рівня: аналіз, синтез і систематизація праць авторів із проблеми дослідження соціальних мереж; логіко-системний, проблемно-цільовий, порівняльний аналіз 3 метою теоретичного обгрунтування особливостей навчальних додатків соціальних мереж.

Результати. Як відомо, поняття «соціальні мережі» до наукового обігу введено англійським соціологом Джеймсом Барнсом у 1954 році. Під суттю даного поняття автор розумів складне переплетення соціальних стосунків. У 1959 році це поняття почало розглядатися угорськими математиками, які розвинули теорію соціальних мереж і першими запропонували поняття 
коефіцієнта кластеризації, тобто ступеня близькості між неоднорідними групами (коли людина розширює свої зв'язки через знайомих).

Перша спроба створення соціальних мереж була здійснена у середині 90-х років XX століття. 3'явилися такі веб-інструменти, що встановлювали зв'язки між користувачами в межах одного сайту. Спочатку користувачі підтримували ділові контакти. Деякі мережі були закритими, інші відкритими. Зі зростанням Інтернет-мереж число користувачів Інтернет зросло.

Сьогодні терміном «соціальні мережі» позначають будь-яку соціальну структуру i різноманітність соціальних взаємин, однак у сучасному науковому дискурсі ним позначають, насамперед, он-лайнові мережі, які створюються у віртуальному просторі й забезпечують дистанційне спілкування та встановлення взаємозв'язків між учасниками так званої мережевої структури. Часто це поняття, на думку О. Власенко (Vlasenko, n. d.), пов'язують із поняттям «коннективізм» (запропоноване Джорджем Сіменсом), яке грунтується на теоріях мережі, складно організованих та самоорганізованих системах.

У своєму дослідженні С. Івашньова (Ivashnova, 2012) описує «соціальну мережу» як «віртуальний майданчик, що забезпечує своїми засобами спілкування, підтримку, створення, розбудову, відображення та організацію соціальних контактів, у тому числі й обмін між користувачами».

Аналіз історії виникнення соціальних мереж дозволяє визначити наступні етапи їх розвитку:

- 1995 рік - Classmates.com - перший аналог соціальної мережі в Інтернеті.

- 1997 рік - SixDegrees - сервіс, який дозволяв створення власних профілів, організацію груп.

- 1999 рік - LiveJournal - блог-платформа, соціальна мережа для ведення он-лайн щоденників (блогів), створення окремих персональних блогів, розташованих на цій платформі. 
- 2002 рік - Friendster - соціальна мережа, яка призначена для пошуку нових друзів для спілкування.

- 2003 рік - Linkedln - соціальна мережа, орієнтована на ділових людей і створення ними ділових контактів.

- 2004 рік - Facebook - найбільша у світі соціальна мережа, що почала працювати як мережа для студентів окремих американських університетів.

- 2005 рік - Youtube - відеохостінговий сайт, соціальна мережа, яка надає користувачам послуги зберігання, доставки та огляду відео контенту.

- 2006 рік - Twitter - соціальна мережа, яка є мережею мікроблогів, дає змогу користувачам надсилати короткі текстові повідомлення.

- 2009 рік - Pinterest - соціальний Інтернет-сервіс, фотохостінг, дозволяє користувачам додавати в режимі он-лайн зображення і розміщувати їх у тематичні колекції, ділитися ними з іншими користувачами.

- 2011 рік - Google + - багатомовна соціальна мережа та ідентифікаційна служба.

Так, світова статистика у \% відношенні на липень 2018 виглядає таким чином, рис.1, за джерелом gs.statcounter.com.

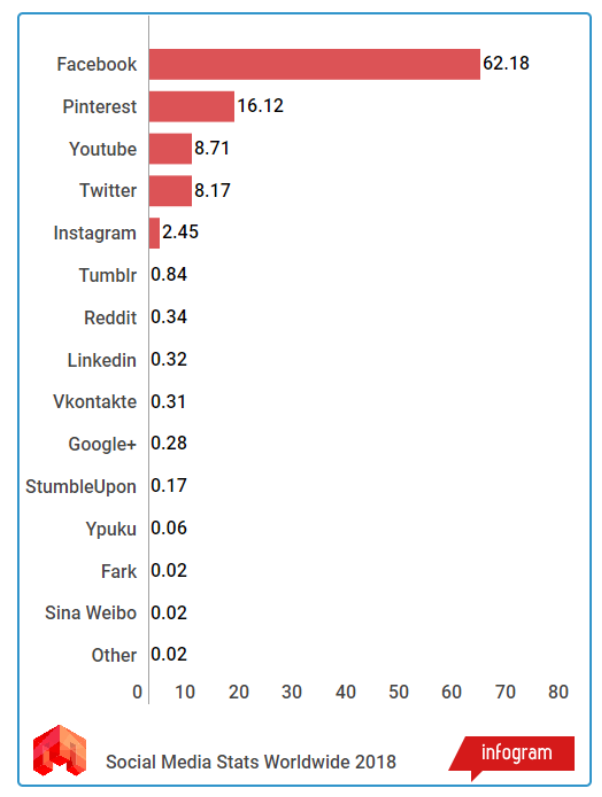

Рис.1. Світова статистика соиуіальних мереж у \% відношенні на липень 2018 p. 
Враховуючи вище зазначені дані, можна стверджувати, що найбільш популярні соціальні мережі - Facebook, Pinterest, Youtube, Twitter та Instagram. Pinterest та Instagram - це соціальні мережі для роботи із зображеннями, Twitter - це мережа мікроблогів, Youtube - це мережа для роботи з відео контентом.

На нашу думку, саме Facebook, який має більш розширений навчальний фунціонал, що надає змогу студенту та викладачу зробити більш різноманітну та плідну навчальну роботу, слід розглядати як ефективну соціальну мережу для навчання.

Розглянемо основні характеристики та можливості найбільшої соціальної мережі Facebook, придатної для навчання. Останнім часом зазначена компанія приділяє особливу увагу освіті. Багато закладів вищої освіти використовують засоби та навчальні додатки Facebook для публікації новин, спілкування, збирання інформації, залучення абітурієнтів, надання студентам потрібної інформації, здійснення наукової діяльності.

Крім того, викладач може створити власну групу для роботи зі студентами. Викладач групи заповнює навчальний контент - це завдання, опитування, тести, відео контент, різноманітні зображення та навчальні пости. Наявність власної навчальної групи у соціальних мережах робить викладача більш сучасним, а студентів - більш охочими до навчання. Студент у будь-який час має доступ до навчального матеріалу, що робить більш зручним процес навчання.

У свою чергу, викладач має власні переваги, наприклад, він може одночасно викладати навчальний матеріал декільком групам студентів, надавати ще більше додаткового матеріалу, який не встиг розглянути на занятті, або більше додаткового матеріалу, який не є плановим у навчальний час. Тобто, навчальний матеріал стає більш доступним, надана інформація стає набагато цікавішою та різноманітнішою завдяки мережі Facebook та його навчальним додаткам. 
При цьому необхідно розглянути наступні моменти, на які має звернути увагу викладач, щоб організувати навчання в соціальній мережі:

$\checkmark \quad$ мета організації роботи;

$\checkmark \quad$ зміст навчального контенту (якщо це навчальна група, доцільно уникати розважального матеріалу);

форма розміщення навчального матеріалу (пост, опитування, дискусійний форум, відео матеріал, самоосвіта, тест, зворотній зв’язок);

$\checkmark$ наявні у викладача навички роботи з сучасними технологіями;

$\checkmark$ доступні технічні засоби, підключення до мережі wi-fi чи наявність хмарних технологій.

При цьому існує ще багато навчальних он-лайн додатків, які роблять навчання більш простим та різноманітним. Здійснивши аналіз навчальних додатків, можна виділити наступні:

Flashcards - популярний у викладачів додаток для студентів. У ньому можна легко i швидко створювати наочні зображення, прикріплювати зображення до термінів, дефініцій, описів.

Docs - додаток дозволяє створювати та обмінюватися документами Microsoft Office у мережі Facebook.

SlideShare - цей додаток дає можливість створення презентацій для відправки студентам слайд-шоу.

Ted - це додаток, в якому транслюють щорічні конференції. Теми конференцій різноманітні: наука, мистецтво, дизайн, політика, культура, освіта, розваги та ін.

Babylon - електронний словник та програма автоматичного перекладу, яка підтримує 75 мов.

Studify - це додаток, який показує розклад занять для студентів.

weRead - цей додаток дозволяє ділитися думками про книги, писати свої коментарі та дізнаватися думку інших читачів про книги.

Study Groups - за допомогою цього додатку можна реалізувати груповий проект. 
Отже, можливість роботи з соціальними мережами та їх навчальними додатками сприяє більш швидкій і зручній роботі з навчальним матеріалом. Разом 3 тим, надає можливість студентам колективно оцінювати навчання для всіх учасників навчальної групи та можливість викладачу спостерігати за результатами роботи кожного студента.

Використання соціальних мереж у навчальній діяльності має багато переваг, а саме: комфортне середовище; усі учасники мережі створюють мережевий навчальний контент; можливість спільної праці; наявність форуму, «стіни», чату; кожен студент-користувач може створити власний блог; можливість простежувати активність користувачів, - вважає К. Балабанова (Balabanova \& Vakariev, 2013).

Вивчаючи роботу соціальних мереж, дослідниця визначає наступні переваги використання соціальних мереж у навчальному процесі, а саме:

- реалізація творчого потенціалу студента;

• можливість групової діяльності студентів;

- читання новин, коментування різноманітних матеріалів;

- удосконалення навичок чітко й лаконічно висловлювати думку;

- обговорення різноманітних питань і тем стосовно навчальної дисципліни;

- опублікування і отримання потрібних відомостей про розклад занять, навчання, завдання.

- спілкування між студентами та викладачами, які знаходяться на відстані;

- обмін новинами;

- різноманітність форм комунікації (опитування, голосування, форуми, коментарі, підписки, відправка персональних повідомлень та ін.),

- постійна взаємодія студента і викладача в мережі у зручний час;

- наявність мобільної версії сторінок, що допомагає студенту i викладачу у зручний час отримати навчальну інформацію 3 будь-якого пристрою; 
- можливість швидкого отримання навчальної інформації чи консультації викладача (Balabanova \& Vakariev, 2013).

А. Яцишин зазначає, що соціальні мережі можна застосувати для: «групового навчання (для роботи в навчальних міні-групах); персонального навчання (для самоосвіти); випадкового навчання (можливість пізнавати щось нове несвідомо); внутрішнього навчання (використання 3 метою інформування функціонування навчального закладу та заходів, пов’язаних 3 цим)» (Yatsyshyn, 2014). Безперечно, соціальні мережі можна використовувати і для позааудиторної роботи.

У своєму дослідженні А. Яцишин виокремлює основні характеристики функціонування віртуальних соціальних мереж:

$\checkmark \quad$ «ідентифікація особи - відомості про особу (навчальний заклад, дата народження, улюблені книги, фільми та ін.);

$\checkmark$ присутність на сайті - можна дізнатися, хто 3 користувачів у даний момент є в мережі, і долучитися до спілкування;

$\checkmark \quad$ статус стосунків між користувачами - визначення стосунків між користувачами (друзі, члени родини, однокласники та ін.);

комунікація в мережі - спілкування 3 кількома користувачами мережі синхронно та асинхронно (особисте і групове спілкування, коментарі й оцінка фото, відео, рефератів, есе тощо);

$\checkmark$ міні-групи - можна створити в середині віртуальної соціальної мережі об’єднання за інтересами;

$\checkmark$ обмін матеріалами - $€$ можливість поділитись 3 іншими користувачами (документами, фото, відео, закладками, презентаціями, книгами в цифровому форматі тощо)» (Yatsyshyn, 2014).

Проте, на наш погляд, використання соціальних мереж іноді має певні недоліки - схильність до залежності, занурення у віртуальну реальність тощо, які, здебільшого, є психологічними порушеннями.

Обговорення. У дослідженнях сучасних науковців, як-от К. Балабанової щодо використання соціальних мереж у професійній 
діяльності викладача ВН3 (Balabanova \& Vakariev, 2013), Д. Бодненко 3 використання можливостей соціальної мережі Facebook для навчання майбутніх журналістів (Bodnenko, Yashchenko \& Borshch, 2012), О. Власенко 3 використання сучасних технологій для контролю рівня навчальних досягнень (Vlasenko, n. d.), С. Івашньової щодо використання соціальних сервісів та соціальних мереж в освіті (Ivashnova, 2012), I. Костікової 3 навчання студентів англійської мови засобами сучасних технологій (Kostikova, 2018), А. Яцишин із застосування віртуальних соціальних мереж для потреб загальної середньої освіти (Yatsyshyn, 2014), було визначено, що порівняльний аналіз отриманих нами даних повністю співпадає 3 результатами досліджень попередників, які вивчали це питання. Іншими словами, проведене дослідження підтверджує висновки інших науковців щодо необхідності оновлення шляхів, форм, методів, засобів, прийомів навчання за допомогою використання соціальних сервісів, соціальних мереж та їх навчальних додатків зі студентами у закладах вищої освіти.

Висновки. Таким чином, на сучасному етапі розвитку суспільства все більшого поширення набуває питання ефективності використання соціальних мереж в освітньому процесі. Очевидно, що вже неможливо викладати дисципліни традиційно, тому соціальні мережі у навчанні надають можливість додаткового обговорення, консультування, спілкування 3 кількома групами студентів водночас. Використання соціальних мереж для навчання студентів надає змогу постійно слідкувати за виконанням завдань, що дозволяє налагодити оптимальну співпрацю між викладачем і студентом.

\section{ЛITEPATУРА:}

Chernenko, A. V. (2018). Information and Communication Technologies in Higher Education. Proceedings of XXXVII International scientific conference. Scientific book at the present. Morrisville, Lulu Press, 123.

Chernenko, A. V. (2019). Interactive Teaching Methods in Educational Process. III Internet Conference Proceedings "Foreign language in professional training of specialists: issues and strategies". Online book of abstracts, Kropyvnytskyi. Retrieved from: https://www.cuspu.edu.ua/en/iii-international-scientific-and-practical-internetconference-foreign-language-in-professional-training-of-specialists-issues-andstrategies/section-2/8843-interactive-teaching-methods-in-educational-process 
Kostikova, I. I. (2018). Information and communication technologies in students' language learning. International Journal of Education and Science, 1(1-2), 7-14. Retrieved from: DOI: 10.26697/ijes.2018.1-2.01.

Kostikova, I., Viediernikova, T., Holubnycha, L., \& Miasoiedova, S. (2019). The CompetencyBased Approach to Passing First Certificate in English. Revista Romaneasca pentru Educatie Multidimensionala, 11(1), 117-130. Retrieved from: https://doi.org/10.18662/rrem/100

Kostikova, I., Shevchenko, A., Holubnycha, L., Popova, N., Budianska, V. (2019). Use of Machine Translation Technology for Understanding Scientific and Technical Texts. Journal of Theoretical and Applied Information Technology, 97 (4), 1355-1366. Retrieved from: http://www.jatit.org/volumes/Vo197No4/24Vo197No4.pdf

Балабанова К. С. Використання соціальних мереж у професійній діяльності викладача ВН3. Наукові записки Тернопільського начіонального педагогічного університету імені Володимира Гнатюка. Серія : Педагогіка. 2013. № 3. С. 134-139.

Бодненко Д. М. Використання соціальної мережі Facebook для навчання майбутніх журналістів. Науковий вісник інноваційних технологій. 2012. № 1. С. 29-35.

Власенко О. В. Використання інформаційно-комунікаційних технологій для контролю рівня навчальних досягнень. Інформаційно-комунікаційні технологї в освіті та наукових дослідженнях. Режим доступу:http://www.tryus.npu.edu.ua/!type/conference/images/stories/files/tezy/Tom_2/s ection_g.pd

Івашньова С. В. Використання соціальних сервісів та соціальних мереж в освіті. Наукові записки НДУ ім. М. Гоголя. Психолого-педагогічні науки. 2012. № 2. С. 15-17.

Про Національну стратегію розвитку освіти в Україні на період до 2021 року: Указ Президента України 344/2013 від 25 червня 2013. Режим доступу: https://zakon.rada.gov.ua/laws/show/344/2013

Яцишин А. В. Застосування віртуальних соціальних мереж для потреб загальної середньої освіти. Інформаційні технології в освіті. 2014. № 19. С. 119-126.

\section{REFERENCES:}

Balabanova, K. Ye., Vakariev, Ye. S. (2013). Vykorystannia sotsialnykh merezh u profesiinii diialnosti vykladacha VNZ. [Use of social networks in teacher's professional activity in higher education] Naukovi zapysky Ternopilskoho natsionalnoho pedahohichnoho universytetu imeni Volodymyra Hnatiuka. Seriia: Pedahohika, 3, 134-139. (in Ukrainian).

Bodnenko, D. M., Yashchenko, D. O., Borshch, Ya. O. (2012). Vykorystannia sotsialnoi merezhi Facebook dlia navchannia maibutnikh zhurnalistiv [Use of social network Facebook to educate future journalists]. Naukovyi visnyk innovatsiinykh tekhnolohii, 1, 29-35. (in Ukrainian).

Vlasenko, O. V. (n. d.). Vykorystannia informatsiino-komunikatsiinykh tekhnolohii dlia kontroliu rivnia navchalnykh dosiahnen. Informatsiino-komunikatsiini tekhnolohii $v$ osviti ta naukovykh doslidzhenniakh. Retrieved from:http://www.tryus.npu.edu.ua/!type/conference/images/stories/files/tezy/Tom_2/secti on_g.pd (in Ukrainian).

Ivashnova, S. V. (2012). Vykorystannia sotsialnykh servisiv ta sotsialnykh merezh v osviti. [The use of social services and social networks in education]. Naukovi zapysky NDU im. M. Hoholia. Psykholoho-pedahohichni nauky, 2, 15-17. (in Ukrainian).

Pro Natsionalnu stratehiiu rozvytku osvity v Ukraini na period do 2021 roku: Ukaz Prezydenta Ukrainy 344/2013 vid 25 chervnia 2013. [About the National Strategy for the 
Development of Education in Ukraine until 2021: Presidential Decree 344/2013, June, 25, 2013]. Retrieved from: https://zakon.rada.gov.ua/laws/show/344/2013 (in Ukrainian).

Yatsyshyn, A. V. (2014). Zastosuvannia virtualnykh sotsialnykh merezh dlia potreb zahalnoi serednoi osvity. [Application of virtual social networks for the needs of general school education]. Informatsiini tekhnolohii v osviti, 19, 119-126. (in Ukrainian).

Chernenko, A. V. (2018). Information and Communication Technologies in Higher Education. Proceedings of XXXVII International scientific conference. Scientific book at the present. Morrisville, Lulu Press, 123. (in English).

Chernenko, A. V. (2019). Interactive Teaching Methods in Educational Process. III Internet Conference Proceedings "Foreign language in professional training of specialists: issues and strategies". Online book of abstracts, Kropyvnytskyi. Retrieved from https://www.cuspu.edu.ua/en/iii-international-scientific-and-practical-internetconference-foreign-language-in-professional-training-of-specialists-issues-andstrategies/section-2/8843-interactive-teaching-methods-in-educational-process English)

Kostikova, I., Shevchenko, A., Holubnycha, L., Popova, N., Budianska, V. (2019). Use of Machine Translation Technology for Understanding Scientific and Technical Texts. Journal of Theoretical and Applied Information Technology, 97 (4), 1355-1366. Retrieved from: http://www.jatit.org/volumes/Vo197No4/24Vol97No4.pdf (in English).

Kostikova, I., Viediernikova, T., Holubnycha, L., \& Miasoiedova, S. (2019). The CompetencyBased Approach to Passing First Certificate in English. Revista Romaneasca pentru Educatie Multidimensionala, 11(1), 117-130. Retrieved from https://doi.org/10.18662/rrem/100 (in English).

Kostikova, I. I. (2018). Information and communication technologies in students' language learning. International Journal of Education and Science, 1(1-2), 7-14. Retrieved from: DOI: 10.26697/ijes.2018.1-2.01 (in English).

\begin{tabular}{|c|c|}
\hline Інформація про автора: & Information about the author: \\
\hline Володимирівна: & Volodymyrivna: \\
\hline ORCID: $\quad$ https://orcid.org/0000-0003-4097- & https://orcid.org/0000-0003-4097- \\
\hline 6246; аспірантка кафедра загальної педагогіки і & 6246; PhD Student of Department of General \\
\hline вищої школи, & Pedagogy and Higher School Pedagogy, \\
\hline національний педагогічний університет імені & H. S. Skovoroda Kharkiv National Pedagogical \\
\hline $\begin{array}{l}\text { Г. С. Сковороди, вул. Валентинівська, 2, м. } \\
\text { Харків, Україна, } 61166 . \\
\text { e-mail: nastasiyache2101 @gmail.com }\end{array}$ & $\begin{array}{l}\text { University, Valentynivska street, 2, Kharkiv, } \\
\text { Ukraine, } 61166 . \\
\text { e-mail: nastasiyache2101 @gmail.com }\end{array}$ \\
\hline
\end{tabular}

Цитуйте цю статтю як: Черненко А.В. Використання соціальних мереж для навчання студентів у закладах вищої освіти. Теорія та методика навчання та виховання. 2019. № 46 , C. 166-178. DOI: $10.34142 / 23128046.2019 .46 .13$

Дата надходження статті до редакції: 15.04.2019

Стаття прийнята до друку: 30.04.2019 